\title{
Sosialisasi Pengolahan Sampah Anorganik Menjadi Eco Brick (Keranggan, Setu, Tangerang)
}

\author{
Marchelia Gupita Sari ${ }^{1}$, Nurul Lestari Hasanuddin², Abdullah Hibrawan ${ }^{3}$ \\ 1,2,3 Institut Sains dan Teknologi Pradita \\ marchelia.gupita@pradita.ac.id,nurul.lestari@pradita.ac.id, abdullah.hibrawawn@pradita.ac.id
}

\begin{abstract}
Abstrak
Eco-brick merupakan bata ramah lingkungan hasil dari teknik pengelolaan sampah plastik yang terbuat dari botol-botol plastik bekas PET yang di dalamnya telah diisi berbagai sampah plastik hingga penuh, kemudian dipadatkan sampai menjadi keras mencapai jumlah bobot tertentu. Eco-brick dapat menjadi salah satu material alternatif arsitektural yang terjangkau. Metode yang digunakan dalam pelaksanaan kegiatan Pengabdian kepada Masyarakat ini adalah sosialisasi dan presentasi tentang pembuatan eco-brick kepada masyarakat Kelurahan Keranggan, Setu, Tangerang yang menghadapi isu permasalahan sampah anorganik di lingkungannya. Diharapkan dengan adanya sosialisasi dengan presentasi kepada masyarakat, dapat meningkatkan partisipasi masyarakat dalam pengelolaan sampah berkelanjutan. Hasil kegiatan Pengabdian kepada Masyarakat adalah kenaikan tingkat kesadaran masyarakat dalam pengelolaan sampah organik dan nonorganik, serta pemahaman masyarakat yang lebih baik mengenai material bangunan alternatif ramah lingkungan dari eco-brick.
\end{abstract}

Kata Kunci : Arsitektur, Eco-brick, Keranggan

Abstract

Eco-brick is an environmentally friendly brick management technique for plastic waste made from used PET plastic bottles in which various plastic bins have been filled to the brim, then compacted until it becomes hard to reach a certain amount of weight. Eco-brick can be one of the alternative affordable architectural material. The method conducted the implementation of Community Service activities is the socialization and presentation on eco-bricks assembly to the people of Kelurahan Keranggan, Setu, Tangerang, who face the issue of anorganic waste. Through socialization with presentations to the community, it is expected that it can increase the community participation in sustainable waste management. The results of Community Service activities are the increase in the level of community awareness in organic and inorganic waste management, as well as community better understanding of environmentally friendly alternative building materials from eco-brick.

Keywords : Architecture, Eco-brick, Keranggan

\section{PENDAHULUAN}

Berbagai kegiatan manusia, baik dari kegiatan industri maupun rumah tangga dewasa ini telah menghasilkan limbah, di mana produksi limbah berlebihan tentunya dapat berdampak buruk terhadap lingkungan. Sampah merupakan limbah padat yang dinilai tidak memiliki nilai ekonomi 
apapun yang dapat mencemari lingkungan, serta beracun bagi manusia mengacu pada UU No.18 Tahun 2018. Sampah dibedakan menjadi dua, yaitu sampah organik dan sampah anorganik. Sampah organik adalah limbah yang dapat membusuk dan dapat diuraikan, sedangkan sampah anorganik adalah sampah yang tidak dapat membusuk dan tidak dapat diuraikan. Dampaknya sangat negatif bagi manusia, terutama bagi kesehatan. Metode landfill, tempat pembuangan sampah akhir, selama ini populer untuk digunakan walaupun bukanlah solusi ideal karena zat-zat kimia sampah meresap ke biosfer yang nantinya akan kembali ke dalam tubuh manusia.

Dampak negatif sampah plastik adalah terganggunya kesehatan manusia. Material plastik merupakan material yang mudah terbakar mengakibatkan ancaman terjadinya kebakaran pun tinggi. Asap hasil pembakaran bahan plastik sangat berbahaya karena mengandung gas -gas beracun seperti hidrogen sianida $(\mathrm{HCN})$ dan karbon monoksida (CO).

Dewasa ini, permasalahan sampah anorganik plastik mendapatkan sorotan serius karena jumlah sampah hasil intensitas pemakaiannya yang tinggi. Karena bentuknya praktikal, plastik banyak digunakan sebagai peralatan rumah tangga menggantikan kayu, logam, kertas, dan kaca. Plastik yang sehari - hari banyak digunakan oleh manusia secara umum plastik botol PET yang tidak mudah terurai. Botol PET berdasarkan Aeghee (2014) berbahaya jika dipanaskan atau memuat air panas karena dapat mengakibatkan penyakit kanker bagi manusia.

Berdasarkan PET Resin Association (2015) PET adalah material yang 100\% dapat di daur ulang. Selain kemasan botol, PET resin hasil daur ulang dapat juga digunakan untuk memproduksi pakaian, onderdil kendaraan, karpet dan lain - lain. Angka daur ulang PET di negara-negara maju Amerika Serikat dan Eropa berturut - turut sekitar $31 \%$ dan 52\% pada tahun 2012.

Jumlah sampah anorganik plastik, khususnya botol PET meningkat dari tahun ke tahun berbanding terbalik terhadap kesadaran masyarakat untuk melaksanakan kegiatan $R 3$ (reduce, reuse, recycle) yang masih sangat rendah. Jika dilihat dari efektivitasnya, program tersebut sebenarnya efektif dalam mengendalikan masalah sampah plastik yang ada di Indonesia. Kurangnya pemahaman masyarakat terhadap program R3 menjadi salah satu latar belakang kegiatan pengabdian kepada masyarakat menyosialisasikan pengolahan sampah plastik dengan 'recycle'.

Menilik penduduk Tangerang Selatan yang memproduksi sampah hingga 350 ton dengan (berdasarkan laman situs wartakota.tribunnews.com), hal ini senada dengan kondisi di Kelurahan Keranggan di Kecamatan Setu Tangerang.

Kecamatan Setu merupakan pemekaran dari Kecamatan Cisauk, Tangerang dengan batas sungai Cisadane, sebelah barat sungai Cisadane masuk Kec. Cisauk dan sebelah Timur masuk Kec. Setu. Kelurahan Keranggan merupakan desa home industry makanan ringan. Dari kondisi eksisting Kelurahan Keranggan, terdapat sampah anorganik, sampah plastik yang dibuang sembarangan dan menumpuk di sekitar rumah warga. Terdapat bank sampah yang dikelola warga, namun pelaksaanannya masih belum efektif dan efisien.

Ecobrick adalah botol plastik yang diisi oleh sampah anorganik plastik, yang kemudian dipadatkan. Ecobrick ditemukan oleh oleh Russell Maier dan Ani Himawati dari Global Ecobrick Alliance (GEA). Ecobrick dapat diaplikasikan dalam arsitektur, yaitu sebagai material alternatif bangunan. Ecobrick dapat berfungsi sebagai elemen struktur bangunan maupun elemen nonstruktur bangunan, misalnya sebagai pengisi dinding yang bersifat ornamental. Aplikasi yang bersifat struktur saat ini banyak digunakan sebagai pengisi box planter di ruang-ruang terbuka warga, maupun sebagai bahan bangunan menggantikan batu bata. Untuk lingkup komunitas, proyek-proyek komunitas dengan ecobrick, baik berupa arisan, pameran, membuat furniture, seperti meja maupun bangku, alat permaian, membangun taman sekolah atau kebun sayur dalam perumahan, akan membawa masyarakat secara bersama-sama bergerak membersihkan dan menghijaukan lingkungan (Maier, Angway \& Himawati, 2017).

$$
\text { Teknologi Tepat Guna }
$$


Oleh karena itu, dalam Kegiatan Pengabdian kepada Masyarakat ecobrick dipilih sebagai solusi yang ditawarkan untuk menggunakan kembali sampah plastik karena ecobrick merupakan pemberdayaan individu dalam sebuah komunitas yang harus berkomitmen untuk pemanfaatan sampah mereka dari sumbernya. Teknik pembuatan ecobrick pun tergolong sederhana, mudah dimengerti oleh masyarakat berbagai latar belakang maupun usia dan hanya memerlukan bahan dan peralatan yang sederhana.

\section{METODE}

Langkah-langkah sistematis yang dilakukan dalam kegiatan pengabdian masyarakat adalah sebagai berikut:

\section{Tahapan Persiapan}

Tahapan persiapan dilakukan dengan cara melakukan observasi sebanyak 2 (dua) kali ke Kelurahan Keranggan Kecamatan Setu Tangerang. Tahapan observasi bertujuan untuk mengetahui titik-titik penumpukan sampah di sekitar rumah warga, dan melakukan wawancara terhadap sejumlah warga yang melakukan proses produksi makanan ringan. Wawancara terhadap pihak koperasi untuk mendapatkan data mengenai warga Kelurahan Keranggan, terutama RT 12 dan RT 13 untuk menyampaikan teknis kegiatan. Setelah itu, dilakukan wawancara purposive sampling warga yang memiliki home industry. Tahapan persiapan adalah menginformasikan ke warga atau masyarakat untuk mengumpulkan botol PET bekas dengan ketentuan sebagai berikut; botol PET bekas merupakan botol air mineral kemasan dengan kapasitas 600 ml,botol PET bekas merupakan botol bekas yang masih utuh sesuai dengan studi literatur mengenai ecobrick. Tujuan meminta masyarakat untuk mengumpulkan botol PET bekas adalah sebagai bahan untuk mencontohkan pembuatan saat kegiatan pelaksanaan sosialisasi digelar.

Tahapan selanjutnya adalah mempersiapkan alat dan bahan untuk pembuatan model ecobrick dalam pengelolaan sampah plastik. Mahasiswa berpartisipasi sebagai pembuat model ecobrick. Workshop internal ecobrick dilakukan oleh tim Pengabdian kepada Masyarakat Program Studi Arsitektur dengan mahasiswa program studi sebagai bagian dari materi pembelajaran.

Materi tentang ecobrick didapatkan dari studi literatur oleh mahasiswa yang kemudian dibuat poster infografis dengan konten langkah-langkah pembuatan ecobrick dan contoh desain dengan material ecobrick yang dapat diaplikasikan oleh warga, seperti sebagai berikut;

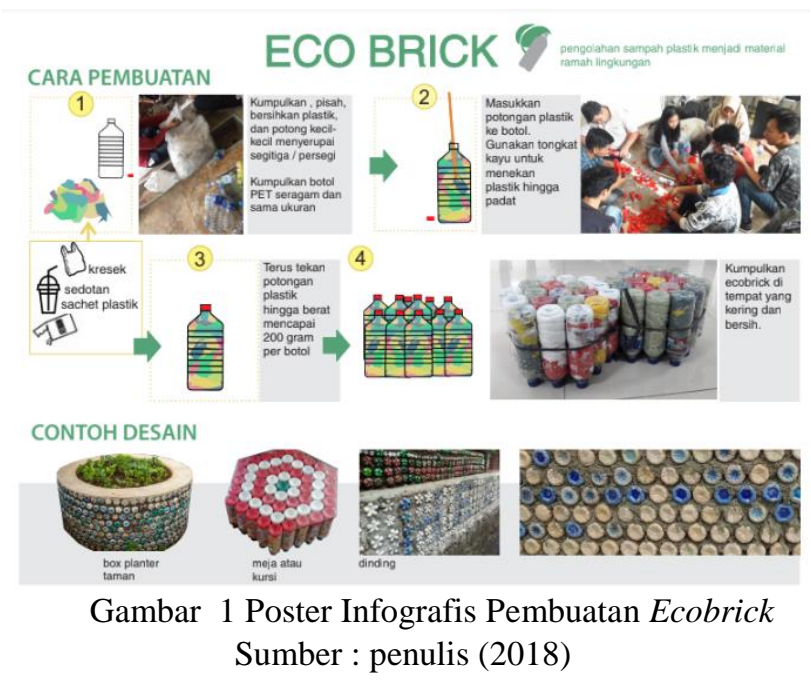

Prosedur Pembuatan ecobrick yang telah dilakukan oleh mahasiswa tim Pengabdian kepada Masyarakat adalah sebagai berikut :

a. pengumpulan botol-botol plastik bekas kemasan minuman (air mineral) $600 \mathrm{ml}$. Botol bekas kemasasn minuman dicuci hingga bersih, lalu dikeringkan

b. pengumpulan berbagai macam kemasan plastik, yaitu kantong kresek, kemasan mie instan, minuman instan, plastik pembungkus, tas plastik dan sebagainya.

c. pemasukan segala jenis plastik yang ada di ke dalam botol-botol plastik air mineral kemasan

d. pemasukan bahan plastik ke dalam botol plastik harus dimampatkan hingga sangat padat dan mengisi seluruh ruang botol plastik. 
e. pemadatan ecobrick menggunakan alat yang terbuat dari bambu atau kayu (seperti tongkat bambu atau kayu).

f. Penimbangan berat botol hingga memenuhi berat minimum 200 gram. Setelah itu, mengulangi cara di atas pada botol yang sama hingga memiliki beberapa ecobrick. Kegiatan persiapan bersama mahasiswa menghasilkan 25 ecobrick untuk disosialisasikan kepada masyarakat.
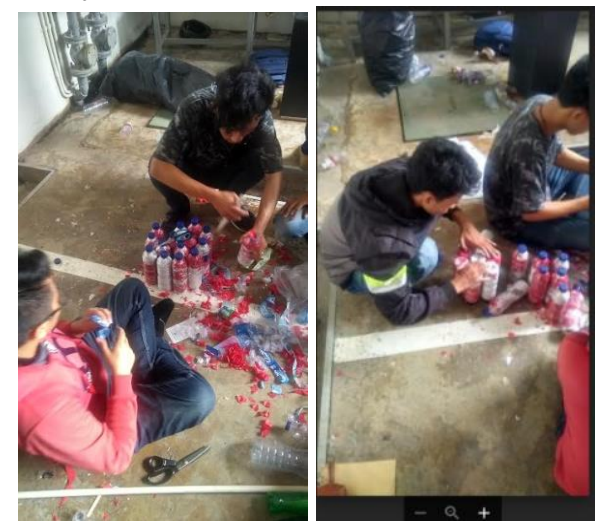

Gambar 2 Kegiatan workshop mahasiswa dan Tim Pengabdian kepada Masyarkat dalam membuat contoh material ecobrick yang akan disosialisasikan kepada masyarakat

\section{Tahapan Pelaksanaan}

Tahapan pelaksanaan adalah kegiatan melakukan kegiatan Sosialisasi Pengolahan Sampah Anorganik Menjadi Eco Brick secara door to door dengan metode purposive sampling sesuai dengan data yang diberikan oleh pihak koperasi dan Ketua RT setempat. Pelaksanaan kegiatan dilakukan pada hari Kamis, tanggal 29 November Tahun 2018. Mahasiswa dibagi menjadi 5 (lima) tim untuk mendatangi rumah-rumah warga, terutama rumah warga yang memiliki mata pencaharian sebagai pelaku home industry. Setiap tim membawa kurang lebih 5 (lima) unit ecobrick dengan tujuan dapat menjadi percontohan bagi warga yang akan mempraktekkan membuat ecobrick.

Pengumpulan data berupa kuisioner sederhana diberikan kepada masyarakat mengenai pengetahuan terhadap pengolahan sampah anorganik dan pengetahuan masyarakat terhadap ecobrick. Pengumpulan kuisioner dibagi menjadi 2 (dua) tahap, yaitu tahap pertama sebelum dan ketika dilakukan sosialisasi dan tahap kedua, sesudah dilakukan sosialisasi oleh mahasiswa.

\section{HASIL DAN PEMBAHASAN}

\section{Pengetahuan Masyarakat tentang Pengolahan Sampah Anorganik}

Dari 20 (dua puluh) rumah yang disurvei dan akan dilakukan sosialisasi oleh mahasiswa dan tim PkM, didapatkan bahwa pada awalnya sebanyak $36 \%$ masyarakat belum mengetahui bagaimana pengolahan sampah organik dan sampah anorganik. Masyarakat belum sepenuhnya tersosialisasikan mengenai konsep R3 (reduce, reuse, recycle) walaupun sudah terdapat masyarakat yang mengetahui kategori sampah organik dan norganik dan sistem pemilahan sampah rumah tangga.
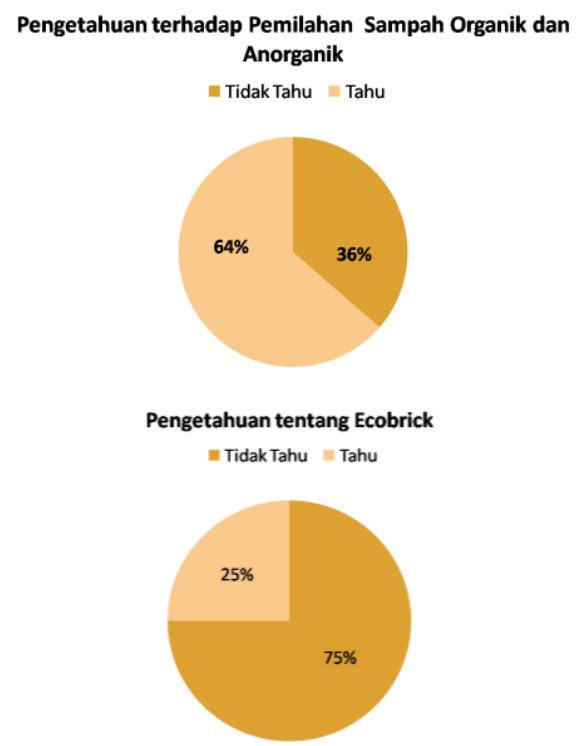

Gambar 3 Bagan Hasil Survei Pengetahuan Masyarakat tentang pengolahan sampah organik

Sample Masyarakat Kelurahan Keranggan RT.12 dan RT 13 menunjukkan bahwa $75 \%$ tidak mengetahui istilah 'ecobrick', sedangkan 25\% mengetahui ecobrick karena pernah melihat di tayangan televisi, sosial media, dan mengetahui dari penyuluhan yang pernah dilihat di luar kegiatan Pengabdian kepada Masyarakat yang dilaksanakan

Teknologi Tepat Guna 
oleh tim. Material ecobrick yang telah digabung berencana untuk dapat dijual atau dimanfaatkan oleh masyarakat.

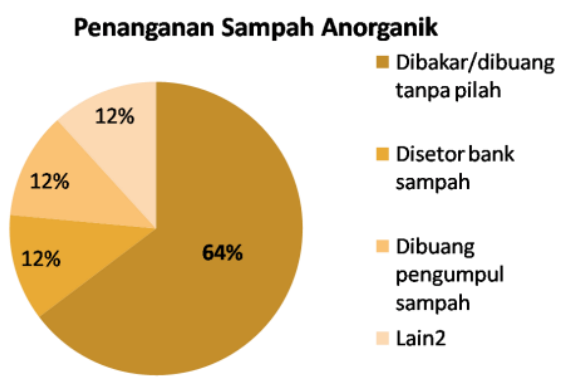

Gambar 4 Bagan Penangangan Sampah Anorganik Masyarakat

Sampah anorganik tidak diberi perlakuan khusus oleh masyarakat, dan tidak melalui proses pemilahan yang membedakan pembuangan sampah organik. Berdasarkan hasil wawancara, hal itu tidak dilakukan karena satu titik pengumpulan sampah untuk bank sampah yang telah ada di wilayah RT tersebut belum berjalan secara efektif sehingga belum ada urgensi untuk memisahkan sampah anorganik, terutama sampah botol plastik dengan sampah anorganik. Masyarakat yang menjawab 'tidak tahu' merasa kesulitan untuk menjelaskan lebih lanjut, atau dengan penjelasan yang sumir serta tidak jelas.

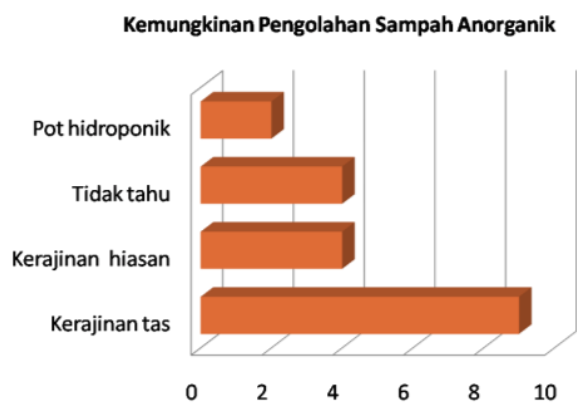

Gambar 5 Respon Masyarakat terhadap Kemungkinan Pengolahan Sampah Anorganik berdasarkan wawancara

Berdasarkan hasil wawancara, diketahui bahwa masyarakat merespon kemungkinan pengolahan sampah anorganik sebagai kerajinan tas, kerajinan hiasan rumah atau hiasan karya seni, pot hidroponik, dan tidak tahu. Ecobrick sebagai material alternatif untuk elemen arsitektur rupanya belum populer dan dikategorikan sebagai 'kerajinan hiasan' oleh masyarakat setelah dijelaskan. Hal ini ditanggapi oleh tim dengan memperkuat konten kegiatan sosialisasi dengan menampilkan foto-foto desain produk maupun arsitektur yang berasal dari ecobrick.

2. Kegiatan Sosialisasi Door to Door oleh Mahasiswa dan Tim Dosen Institut Sains dan Teknologi Pradita

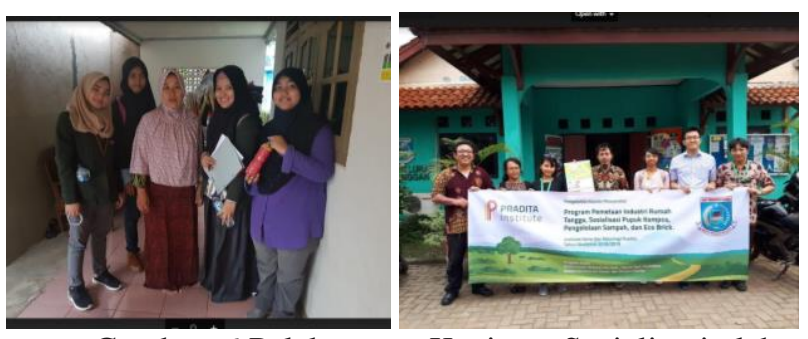

Gambar 6 Pelaksanaan Kegiatan Sosialisasi oleh Mahasiswa dan Tim PKM Institut Sains dan Teknologi Pradita

Lima kelompok melakukan sosialisasi dengan narasi berdasarkan poster infografis dan contoh material ecobrick yang telah dibuat oleh mahasiswa pada 20 (dua puluh) rumah tinggal para pengusaha home industry makanan ringan di RT 12 dan RT 13. Berdasarkan pelaksanaan kegiatan sosialisasi door to door oleh mahasiswa dan tim $\mathrm{PkM}$, didapatkan bahwa pengetahuan masyarakat mengenai kategori dan pemilahan sampah organik dan anorganik masih perlu ditingkatkan.

Dengan sistem sosialisasi door to door, interaksi dan diskusi yang terbangun antara tim PkM dengan masyarakat pun lebih intens dibandingkan dalam forum besar. Pertanyaan dari masyarakat yang kerap muncul adalah sisi ekonomis dari pengolahan sampah anorganik karena pengelolaan sampah anorganik dalam level individu pun memerlukan waktu dan perhatian, sedangkan masyarakat berdalih waktu tersebut dapat digunakan untuk waktu ekstra bekerja. Oleh karena itu, tim PkM menjelaskan bahwa ecobrick dapat memiliki sisi ekonomi jika diolah menjadi 
berbagai kerajinan sekaligus memiliki dampak positif dari sisi lingkungan masyarakat.

\section{Peningkatan Pemahaman Masyarakat terhadap Pengolahan Sampah Anorganik melalui Ecobrick}

Tim PkM melakukan follow up atau tindak lanjut terkait dengan dengan praktik pengelolaan anorganik sampah plastik yang sudah dikerjakan oleh masyarakat sehingga program ini dapat berkelanjutan. Masyarakat cukup antusias untuk mendengarkan sosialisasi dari tim PkM. Masyarakat diharapkan sudah dapat memahami langkahlangkah pembuatan ecobrick dan dapat mempraktikkannya dengan sampah anorganik plastik.

Oleh karena itu, 3 (tiga) minggu dari waktu pelaksanaan sosialisasi, tim PkM meninjau masyarakat yang telah tersosialisasi dengan cara silaturahmi dan melakukan kegiatan wawancara terstruktur maupun kuisioner. Wawancara dan kuisioner ini diadakan untuk mengetahui apakah masyarakat telah melakukan pemilahan sampah sesuai kategorinya dengan baik, ataupun telah mempraktikkan pembuatan ecobrick yang akan digunakan sebagai material utama workshop desain yang akan diselenggarakan oleh tim PkM Institut Sains dan Teknologi Pradita. Kendala kegiatan peninjauan kembali atau follow up adalah tidak hadirrnya masyarakat yang tersosialisasi karena sibuk bekerja berdasarkan penghuni rumah lainnya. Walaupun begitu, terdapat 8 (delapan) rumah yang telah mempraktekkan pengumpulan sampah anorganik berupa pengumpul botol plastik untuk menjadi material ecobrick pada workshop desain ecobrik yang akan dilakukan mendatang oleh Program Studi Arsitektur Institut Sains dan Teknologi Pradita. Ecobrick yang dikerjakan oleh masyarakat diharapkan mampu sesesuai dengan ketentuan warna dasar pengisi pada ecobrick senada dan berwarna cerah agar memiliki nilai estetika.

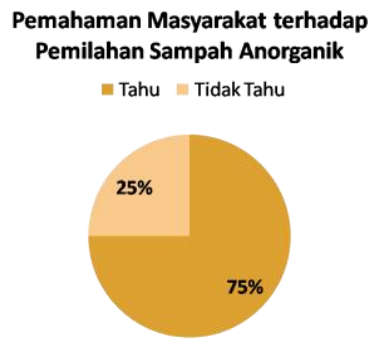

Gambar 7 Bagan Pengetahuan masyarakat tentang pemilahan sampah anorganik setelah kegiatan sosialisasi

Sebanyak $75 \%$ masyarakat yang telah memahami cara pembuatan ecobrick dan pengolahan sampah anorganik mampu memaparkan kembali bagaimana cara pemilahan sampah organik maupun sampah anorganik berdasarkan kuisioner dan wawancara. Untuk jumlah 25\%, masyarakat tidak membuat ecobrick atau melakukan pemilahan sampah anorganik dengan alasan belum dapat konsisten. Walaupun begitu, telah terjadi peningkatan sebesar $11 \%$ terhadap pengetahuan tentang kategori sampah dari sebelum dilakukan sosialisasi.

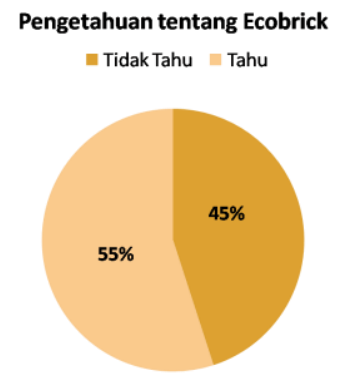

Gambar 8 Bagan Pengetahuan masyarakat tentang ecobrick setelah kegiatan sosialisasi

Pengetahuan tentang ecobrick masyarakat juga mengalami peningkatan dengan adanya masyarakat yang mengumpulkan material sampah anorganik untuk workshop desain yang akan diadakan oleh tim PkM. Masyarakat memilah sampah anorganik plastik dengan cara sederhana, yaitu dipisahkan dari sampah lainnya. Botol PET bekas minuman, bekas minuman sachet yang dipisahkan. Namun, dengan adanya alasan kesibukan kerja masyarakat, dalam kurun waktu 3 
(tiga) minggu target untuk pengumpulan sampah anorganik untuk menjadi ecobrick ternyata belum terpenuhi karena alasan kesibukan kerja dan konsistensi masyarakat. Hal ini dapat ditanggulangi oleh Tim PkM dengan penyediaan material sampah anorganik plastik untuk diolah menjadi ecobrick, dan mendorong masyarakat untuk terus dapat memilah sampah organik dan anorganik, khususnya mengumpulkan botol plastik PET. Terdapat peningkatan sejumlah $20 \%$ pada responden mengenai pengetahuan tentang ecobrick di mana responden telah diperlihatkan contoh-contoh desain kerajinan, non struktur maupun struktur bangunan menggunakan ecobrick.

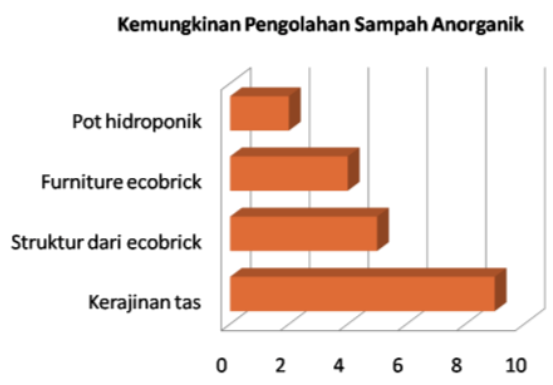

Gambar 9 Kemungkinan Pengelolaan Sampah Anorganik Setelah Kegiatan Sosialisasi

Menilik dari respon masyarakat dalam kemungkinan pengolahan sampah anorganik, terdapat sekitar $50 \%$ responden masyarakat menyebutkan kata kunci 'ecobrick' di bawah kerajinan tas daur ulang plastik kemasan yang selama ini umumnya diterima oleh masyarakat. Masyarakat setuju bahwa ecobrick merupakan material ramah lingkungan karena dapat mengurangi sampah plastik dan mudah dibuat secara individu.

Masyarakat dinilai tertarik untuk mengikuti workshop desain ecobrick. Untuk tahapan awal, akan dibuat workshop desain furniture yang dapat mendukung usaha home industry makanan ringan masyarakat sebelum nantinya ecobrick dikembangkan menjadi struktur bangunan. Diperlukan studi lanjut dari tim PkM tentang ecobricks sebagai pengganti material bangunan konvensional oleh tim PkM.

\section{KESIMPULAN}

Pengolahan sampah anorganik mengurangi dampak negatif penumpukan sampah anorganik di Kelurahan Keranggan, khususnya RT 12 dan RT 13. Dapat disimpulkan bahwa kegiatan Pengabdian kepada Masyarakat dengan melakukan kegiatan sosialisasi disambut relatif baik oleh masyarakat. Masyarakat menerima ide-ide pengolahan sampah anorganik dengan ecobrick.

Oleh karena itu, kegiatan ini perlu dilakukan secara berkesinambungan. Setelah dilakukan kegiatan sosialisasi, terdapat kegiatan workshop desain dengan ecobrick yang diharapkan mampu memberikan gambaran pada masyarakat untuk menggunakan kembali (recycle) sampah anorganik menjadi sesuatu yang memiliki nilai ekonomis sehingga masyarakat dapat meneruskan kegiatan pengolahan sampah menjadi ecobrick. Untuk tahapan selanjutnya, output dari Tim PkM adalah menjadi fasilitator masyarakat yang berminat untuk menjadi peserta workshop dengan alat dan bahan yang diperlukan untuk pembuatan desain kerajinan menggunakan ecobrick dalam rangka pengelolaan sampah plastik yang ramah lingkungan.

\section{UCAPAN TERIMAKASIH}

Ucapan terimakasih disampaikan kepada Institut Sains dan Teknologi Pradita yang telah memberikan kontribusi dalam pelaksanaan kegiatan, serta masyarakat Kelurahan Keranggan yang kooperatif dalam pelaksanaan kegiatan, serta pihak-pihak lain yang telah membantu penyusunan makalah ini.

\section{REFERENSI}

Aghaee, E. M. (2014). "Effects of storage time and temperature on the antimony and some trace element release from polyethylene terephthalate (PET) into the bottled drinking water". Tehran University of Medical Sciences : Tehran. Iran.

$$
\text { Teknologi Tepat Guna }
$$


Maier, R; Angway, I dan Himawati, A. (2017).Plastic, Lingkungan dan Ecobricks.

https://www.ecobricks.org/

(akses 1 Agustus 2019) www.sciencemag.org (diakses pada tanggal 1 Agustus 2019)

www.zerowaste.org (diakses pada tanggal 1 Agustus 2019) 